\title{
Determinants of Capital Structure: Internal Factors (Accounting) versus External Factors (Market)
}

\author{
Risal Rinofah*| Diah Lestari Mumpuni \\ Faculty of Economics, Universitas Sarjanawiyata Tamansiswa Yogyakarta, Indonesia
}

\begin{abstract}
This study aims to examine the role of internal and external factors on the capital structure and specifically will test which factors are dominantly affecting the company's capital structure. The results of this test can be subject to additional discussion on the capital structure both in the classroom and academic space in general because so far, the discussion of factors affecting capital structure is still focused on internal factors of the company alone, especially in Indonesia. This goal will be achieved by observing manufacturing company panel data for 10 years (2006 - 2015). Data will be tested using multiple regression analysis techniques, both with the Common Effect (OLS), Fixed Effect or Random Effect Models. The three models are used to accommodate variations in the characteristics of the sample of companies studied which generally will affect the relationship between variables. The test results show that the best estimation model is Fixed Effect with the finding that the Capital Structure is determined by internal (Accounting) and external (Market) factors, which are negatively affected by Liquidity (Current Ratio), Company Age (Age), and Stock Market Value (Mispricing). This result also shows that companies in Indonesia adhere to the Market timing Hypothesis and Pecking Order Theory in determining the capital structure theory.
\end{abstract}

Keywords: Capital Structure, Internal Factors, and External Factors

\section{Introduction}

The traditional concept states that capital structure has an impact on firm value. This concept was said that capital structure did not affect the value of the company at all. However, because the assumptions that were built were not practical in the real world, new theories emerged such as the Trade-off Theory and the Pecking Order Theory. The trade-off theory states that debt in the capital structure can be increased continuously as the value of the company rises to a certain point where the potential for bankruptcy is higher too. The Pecking Order Theory specifically states that capital structure must be met from internal funds first and then debt. If needed, then through securities such as bonds and stocks. These theories give birth to various empirical tests consistently until now by using various internal indicators such as Growth, Company Size, Company Age, Profitability, Tangibility, etc. (Acaravci, 2015; Cortez, 2012; Harjanti and Tandelilin, 2007; Lim, 2012; Seftianne and Handayani, 2011; Shah and Khan, 2007), while Rus and Ghazali (2014) dan Haron (2014) adding macro indicator like as interest rate, GDP and inflation.

These studies provide inconsistent results and most importantly not many studies that use market variables (external) such as stock prices (overvalued and undervalued) to predict capital structure. According to the Pecking Order Theory, stocks are the last choice as a source of capital, but research by Trinugroho and Rinofah (2011) found that shares that are being overvalued can be an incentive for managers to prioritize shares over debt and internal funds in building their capital structure. This research also supports the new capital structure theory called Market Timing Hypothesis, where

\footnotetext{
* Corresponding author at Jl. Kusumanegara No.157, Muja Muju, Kec. Umbulharjo, Kota Yogyakarta, Daerah Istimewa Yogyakarta 55165. Email: risal.rinofah@ustjogja.ac.id
} 
managers will tend to sell shares when prices are high (overvalued) and buy back when prices are down (undervalued). In other words, this theory suggests the role of external conditions in capital structure decisions.

This study aims to examine the role of internal and external factors on capital structure and specifically to test which factors are dominantly affecting the company's capital structure. This research is expected to provide stakeholders with insights on the role of internal and external factors in predicting the company's capital structure while proving which capital structure theory is dominant in Indonesia. This research is important to be carried out as an additional discussion in the classes of financial management courses and generally in the academic and practical realm given that none of the three theories above can provide a satisfying and conclusive explanation related to the phenomenon of corporate capital structure decisions.

\section{Literature Review Capital structure theory}

Capital structure is a balance between (long-term) foreign capital and own capital. Another researched define capital structure is the mix (proportion) of the company's long-term permanent funding as outlined in debt, preferred stock equity and common stock. Meanwhile, according to (Sartono, 2014), what is meant by capital structure is a balance of the amount of short-term debt that is permanent, long-term debt, preferred shares, and ordinary shares. From this opinion, in essence, the capital structure which is a combination of debt and equity in a company's long-term financial structure illustrates the long-term target of the composition of debt and capital (equity) in a company.

Policies related to the capital structure is a very important issue for the company because the merits of the company's capital structure will have a direct effect on the company's value. Companies that have too much debt have an impact on increasing the risk of bankruptcy due to high fixed costs (interest costs) arising from the use of debt. In this regard, several capital structure theories have been developed specifically to analyze the use of debt to the value of the company and the cost of capital.

\section{Traditional approach}

The traditional approach states that capital structure has an impact on firm value and capital structure can be altered in order to obtain the best company value so that the term optimal capital structure appears. Company value can be increased by using the increasing proportion of debt. By using an increasingly large debt, in the beginning, the company can reduce its capital costs and increase the value of the company. However, the use of debt exceeds a certain amount, resulting in the level of share capitalization increased beyond the benefits derived from the use of debt, so the company's capital costs rise. The increasing cost of the company's capital is also higher due to an increase in debt costs because the risk faced by creditors is greater in line with the increasing amount of debt used by the company.

\section{Theory by Modigliani dan Miller (M\&M)}

In 1958 Modigliani and Miller (1958) suggested that capital structure does not affect the value of the company. This initial opinion is based on the assumption that there are no taxes and bankruptcy costs. Then in the 1960s they included the tax element in their analysis and concluded that companies with high debt had a higher value than companies with low debt. They argue that high debt will bring a positive impact in the form of tax savings (corporate tax rate shield). Thus, if two companies get the same operating profit but one uses debt and pays interest while the other company does not, then the company that pays interest will pay a smaller income tax. Because saving on paying taxes is a benefit for the company owner, the value of companies that use debt will be greater than the value of companies that don't use debt. This argument then gives the conclusion that the best capital structure is to use maximum debt. This is clearly not very realistic because this assumption can only apply to a perfect capital market. In reality, there is no market that is truly perfect so that the high proportion of debt will have an impact on increasing bankruptcy costs, which in turn will reduce the value of the company. The cost of bankruptcy can be quite significant. Research abroad shows bankruptcy costs can reach $20 \%$ which consists of direct and indirect costs. 


\section{Trade-Off Theory}

Critics of the theory put forward by Modigliani-Miller later gave birth to Trade-off theory which tried to provide solutions to the optimal capital structure. This theory was proposed which states that the optimal structure of the model can be achieved by balancing the benefits of the use of debt (tax benefits) with the costs of bankruptcy and the cost of agency problems. Bankruptcy costs arise because the company is declared bankrupt which can be in the form of bankruptcy administration administrative costs and the impact costs are shunned by suppliers who are not willing to re-establish business relations. The cost of agency problem occurs because when the company's debt conditions increase, the potential losses experienced by the debtor are higher than the shareholders. As a result, the debtors will try to tighten supervision in the form of increasing the number of accountants and so on or in the form of rising interest rates.

This trade-off theory has implications that in determining the capital structure, managers must choose between tax savings and the cost of financial difficulties. Companies with a high level of profitability will certainly try to reduce their taxes by increasing their debt ratios so that the additional debt will reduce taxes. In reality, it is rare for financial managers to think that way. The research made observations on the behavior of corporate capital structures in the United States. The research shows that companies with a high level of profitability tend to have a low debt ratio. This is contrary to the opinion of the trade-off theory. The trade-off theory cannot explain the negative correlation between the level of profitability and the debt ratio.

\section{Pecking Order Theory}

In the previous two theories, the focus point is to find the optimal capital composition, while in the third theory it emphasizes the order of the selection of capital funding sources and does not indicate an optimal capital structure. In short, this theory states that the company likes internal financing (funding from the company's operating results in the form of retained earnings). If external funding is needed, the company will issue the safest securities first, starting with the issuance of bonds, then followed by securities that are characterized by options (such as convertible bonds), then finally if they are still inadequate, new shares are issued. In accordance with this theory, there is no optimal target capital structure. Internal funds are preferred because they are assumed to be cheaper in the sense that the company does not need to "open up again" from the spotlight of outside investors. External funds are preferred in the form of debt rather than equity capital for two reasons. First is the consideration of emission costs.

The cost of bond issuance is cheaper than the cost of issuing new shares, this is because the issuance of new shares will reduce the price of old shares. Second, managers are worried that the issuance of new shares will be interpreted as bad news by investors, and make the stock price will go down. This is caused partly by the possibility of asymmetric information between the management and the financiers.

\section{Market-Timing Hypothesis}

This theory is a theory that is often in conflict with Pecking Order Theory and Trade-off Theory in capital structure policy. This theory suggests that choosing between debt and shares is determined by the conditions of fairness (mispricing) of the stock market price itself. When stock prices exceed fairness (overvalued), managers tend to choose stocks as a source of funding for their capital structure, conversely when stock prices are less fair (undervalued) he will prefer debt over shares. A manager will take advantage of mispricing by issuing shares that are overvalued to enjoy low capital costs and instead avoid issuing shares that are experiencing undervalued to avoid high capital costs. This opportunity will encourage managers to implement investment plans that have been made and even have the potential to carry out investments that are actually of low quality. Conversely, managers of undervalued companies will avoid issuing shares even if they need them, as a result of the high cost of capital on undervalued shares. This market-timing effect will generally be more visible in companies experiencing high funding constraints. In companies like this, the cost of share capital is crucial in their investment decisions because shares are a source of funding that they rely heavily on due to difficulties in accessing other sources of funding. As a result, undervalued companies tend to experience underinvest due to low investment opportunities due to limited funding sources and a very high cost of equity to be borne. 


\section{Method \\ Sample}

Data was collected by documentation techniques of manufacturing company financial statement data on the Indonesia Stock Exchange (IDX) during the period 2006-2015 and other relevant sources. Manufacturing companies were chosen as research subjects because the manufacturing industry is the largest contributor to the Indonesian industry as a whole, and in particular in the movement of the stock market on the Indonesia Stock Exchange, making it worthy of being used as a proxy for all shares on the Indonesia Stock Exchange.

\section{Variable}

The dependent variable of this study is the company's capital structure measured using debt to equity ratio (D / E) calculated using the formula: Independent variables consist of internal and external indicators. From previous research findings, the most dominant variable influencing capital structure was chosen, namely profitability, company size, and liquidity. While the external indicators used are the Fairness of the Share Price (Mispricing). Profitability is a measure of a company's ability to generate profits and will be measured by Return on Equity. The size of the company that shows the size of the company is measured by the total value of the company's assets (Munawir, 2014). Liquidity is a measure of a company's ability to meet its short-term obligations measured by the Current Ratio. Mispricing is a picture of the fairness of a company's value that can indicate conditions over reasonability (overvalued) and less reasonable (undervalued). This indicator will be measured using the formula (Trinugroho and Rinofah, 2011):

$$
\begin{aligned}
& \text { Mispricing }(M I S P)=\left(M / B_{\text {Akt }}\right)-(\mathrm{M} / \mathrm{BPre}) \\
& \text { where } \\
& \mathrm{M} / \mathrm{BPre} \quad=\text { market-to-book predicted } \\
& \mathrm{M} / \mathrm{B}_{\text {Act }}=\text { market-to-book actual }
\end{aligned}
$$

The actual market-to-book value will be calculated using the following formula:

$$
\text { M/BAct }=\frac{\text { Total Stock Market Value }}{\text { Total Book Value of Shares }}
$$

While the predicted market-to-book value will be calculated using the following formula (Trinugroho dan Rinofah, 2011):

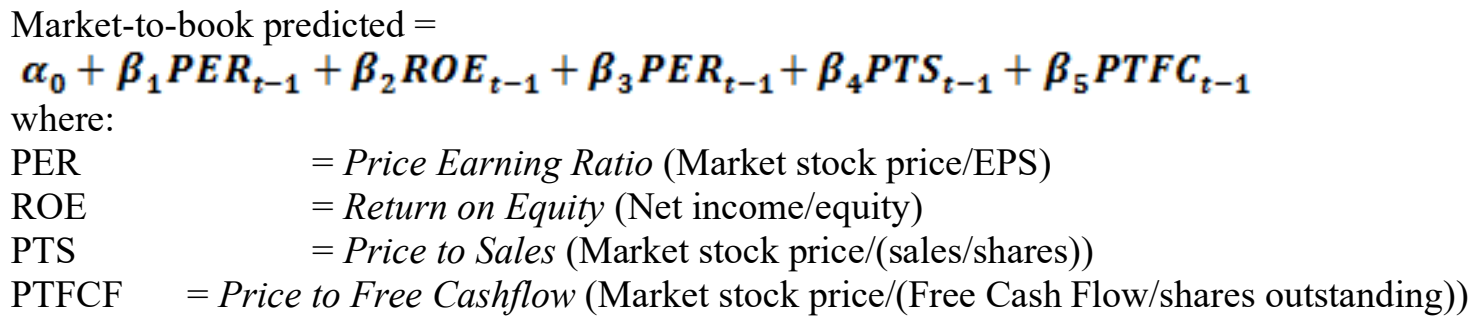

\section{Econometrics model}

We propose the following econometric model.

$$
D / E=\alpha_{0}+\beta_{1} R O E_{t}+\beta_{2} \text { Size }_{t-1}+\beta_{3} C R_{t}+\beta_{4} M I S P_{t}
$$

\section{Data Analysis}

Data analysis techniques through two stages, namely the classic assumption test and hypothesis testing. The classic assumption test consists of tests of normality, heteroscedasticity, multicollinearity, and autocorrelation. The normality test aims to test whether in the regression model, the dependent and independent variables both have normal distributions or not (Ghozali, 2005). The normality test is carried out using the Kolmogorov-Smirnov Test (K-S Test), if the K-S Test result value $>0.05$ then the data distribution does not deviate from the normal curve it is the normality test. Heteroscedasticity 
test aims to test whether in the regression model there is an inequality of variance from the residuals of one observation to the other observations, or it is called homoscedasticity (Ghozali, 2005). A good regression model is homoscedasticity, not heteroscedasticity (Ghozali, 2005). A multicollinearity test is intended to detect symptoms of correlation between one independent variable with another independent variable. The autocorrelation test aims to find out the correlation between the error of the intruder in period $t$ and the error of the intruder in period $t-1$ (before) in a linear regression model. Autocorrelation testing in this study was carried out using Runs Test. Regression models are said to have autocorrelation if the probability is significant at 5\% (Ghozali, 2005).

In the second step, which is hypothesis testing, is carried out by looking at t-statistics and p-value obtained from the regression model. If the p-value is less than 0.05 , we could conclude that the variable is significant. In other words, the independent variable is statistically impacting the dependent variable.

\section{Result}

\section{Data description}

The population of this research is all manufacturing companies listed on the Indonesia Stock Exchange (IDX) for 10 years (2006-2015). During this period, there were several companies that were not used because of the data vacuum, so that there were only 112 companies that were used in total.

Table 1. Descriptive Statistics

\begin{tabular}{lrrrrr}
\hline & $\mathrm{N}$ & Min & Max & Mean & Std. Deviation \\
\hline DER & 1120 & 0.00 & 73.31 & 0.566 & 2.211 \\
ROE & 1120 & -822.06 & 826.83 & 6.574 & 60,917 \\
SIZE & 1120 & 14.54 & 24.11 & 20.231 & 1.501 \\
Current Ratio & 1120 & -1.27 & 34.35 & 1.948 & 1.877 \\
MISPRICING & 1120 & -4.73 & 152.77 & 1.021 & 4.657 \\
AGE & 1120 & 4.00 & 109.00 & 35.178 & 17.527 \\
\hline
\end{tabular}

\section{Classical assumption testing}

The classic assumption test which includes normality test data is not displayed in the study because the function model for testing the hypotheses of this study was analyzed using the panel data regression model. The use of panel data regression models does not require classical assumptions to be tested because, in the use of panel data types, researchers are allowed to identify certain parameters without the need to make strict assumptions or do not require the fulfillment of all classical assumptions of linear regression in OLS. In addition, normality requirements in the data are considered to have been fulfilled because the overall observation of the variable data is the sum of the observational data in cross-section and time series so that the amount of data in this study is considered to be large enough to also be supported by the Central Limit Theorem (CLT) principle.

\section{Choosing estimators}

In estimating models with panel data, there are three model approaches, namely, Common Effects, Fixed Effects, and Random Effects. In testing the estimation model between the Fixed Effect vs Common / Pool Effect methods using the Chow Test. If the result is accepting the null hypothesis that the best model is the Common Effect model, then the test will end there. However, if the results later reject the null hypothesis so that the best model chosen is the Fixed Effect, then the test will continue through the process of comparing it to the Random Effect using the Haussman Test. The model that is considered the best will be the estimation model of the research hypothesis.

The Chow Test is used to determine the best model between the common effect model and the fixed effect model. If the F statistic $>\mathrm{F}$ table (Prob $=$ Significant) then $\mathrm{H} 0$ is rejected, meaning that the fixed effect model is better than the common effect model. If the F statistic $<F$ table (Prob $=$ Not Significant) then $\mathrm{H} 0$ is accepted, meaning that the common effect model is better than the fixed effect model. 
H0: Common Effect Model

H1: Fixed Effect Model

Table 2. Result of Chow Test

\begin{tabular}{lrcc}
\hline \multicolumn{1}{c}{ Effects Test } & Statistic & d.f. & Prob. \\
\hline Cross-section F & 2.207 & $(111.1003)$ & 0.000 \\
Cross-section Chi-square & 244.850 & 111 & 0.000
\end{tabular}

From the test results using Chow-Test shows that the prob value is less than 0.05 ( $\alpha=5$ percent) so that $\mathrm{H} 0$ is rejected or $\mathrm{H} 1$ is accepted. Thus the Fixed Effect model is better than the Common Effect. Based on the provisions, if the selected Fixed Effect vs Common Effect test is the Fixed Effect, then further testing will be carried out on the random effect of the Hausman Test model.

Hausman Test is a test conducted to determine the best model between the fixed effect model and the random effect model. If the Chi-Square statistic $>$ Chi-Square table (Prob $=$ Significant) then H0 is rejected, meaning that the fixed effect model is better than the random effect model. If the Chi-Square statistic $<$ Chi Square table (Prob Not Significant) then H0 is accepted, meaning that the random effect model is better than the fixed effect model.

Ho: Random Effect Model

$\mathrm{H}_{1}$ : Fixed Effect Model

Table 3. Result of Hausman Test

\begin{tabular}{cccc} 
Correlated Random Effects - Hausman Test Chi-Sq. Statistic & Chi-Sq. d.f. & Prob. \\
\hline Cross-section random & 132.781473 & 5 & 0.0000 \\
\hline
\end{tabular}

The test results show that the prob value is less than 0.05 ( $\alpha=5$ percent) so that $\mathrm{H} 0$ is rejected or $\mathrm{H} 1$ is accepted and means that the Fixed Effect model is better than the Random Effect. Based on this test, it can be concluded that the model that will be used in testing the research hypothesis is Fixed Effect. The results of hypothesis testing using the Fixed Effect estimation model are summarized in the following table.

Table 4 Result of Hypothesis Testing

\begin{tabular}{lrlrr}
\hline \multicolumn{1}{c}{ Variable } & Coefficient & Std. Error & t-Statistic & Prob. \\
\hline Constant & 2.253 & 0.264 & 8.507 & 0.000 \\
ROE & 0.000 & 0.000 & 0.092 & 0.926 \\
Size & -0.005 & 0.009 & -0.585 & 0.558 \\
Current Ratio & -0.021 & 0.007 & -2.701 & 0.007 \\
Mispricing & -0.463 & 0.003 & -144.263 & 0.000 \\
Age & -0.056 & 0.004 & -11.536 & 0.000 \\
R-squared & 0.958 & Prob (F-statistic) & & 0.000 \\
Adjusted R-squared & 0.954 & & & \\
F-statistic & 201.640 & & & \\
\hline
\end{tabular}

In accordance with the results of hypothesis testing, it was found that both internal and external factors alike could affect the company's capital structure. Stock Market Value gives the greatest influence with a coefficient of 0.46, followed by, Age of the Company of 0.05 and Liquidity of 0.02 . Sufficient company liquidity indicates the availability of internal funds for the company to fund its operations which is also reflected in its capital structure. In this case, if liquidity is sufficient, the capital component that comes from external (debt) will be smaller. In other words the relationship between liquidity and the amount of debt is negative. This is supported by previous hypothesis testing. Internal funds have always been the first choice for managers because their capital costs are 
relatively cheaper than external funds, such as debt. The use of external funds in addition to burdening the company with the interest to be paid also results in greater external control and can reduce the flexibility of managers in making decisions. In addition, with the obligation to pay costs to external parties, the impact of the company is also burdened by the possibility of bankruptcy that is increasing. This test also proves the existence of Pecking Order Theory which is adopted by the decision-makers in the company. In addition to adequate liquidity, internal factors such as company age also have a negative impact on the company's capital structure. This means that the older the age of the company the lower the amount of debt. The increasing age of the company makes the company has financial maturity, especially internal funds to finance the company which is reflected in its capital structure.

External factors in the form of overvalued or undervalued (Mispricing) are proven to have a negative impact on the company's capital structure. The higher the market price difference with the price of the stock book, the smaller the amount of debt. This shows that the company will utilize its currently high share price as a source of funding rather than as a source of debt by increasing its share issuance. Stock selection will change the proportion of equity so that the ratio of debt to equity will decrease further. These results also support the existence of the Hypothesis Market timing in manufacturing companies that go public in Indonesia. From the above results, it was found that the Market Timing Hypothesis and Pecking Order Theory occur in decision making related to capital structure in Indonesia while proving the rationality of company managers. Managers in Indonesia will look for funding sources that provide the smallest capital costs.

\section{Conclusion}

The test results show that the best estimation model is Fixed Effect with the finding that the Capital Structure is determined by internal (Accounting) and external (Market) factors, which are negatively affected by Liquidity (Current Ratio), Company Age (Age), and Stock Market Value (Mispricing). Stock Market Value gives the greatest influence with a coefficient of 0.46, followed by, Age of the Company of 0.05 and Liquidity of 0.02 . This result also shows that companies in Indonesia adhere to the Market timing Hypothesis and Pecking Order Theory in determining the capital structure theory. Further researchers are advised to broaden the scope of the industry of the research population and use other internal variables of the company.

\section{References}

Acaravci, S.K. (2015), "The Determinants of Capital Structure: Evidence from the Turkish Manufacturing Sector", International Journal of Economics and Financial Issues.

Cortez, M.A. (2012), "The Determinants Of Corporate Capital Structure: Evidence From Japanese Manufacturing Companies", Journal of International Business Research, Vol. 11 No. 3.

Ghozali, I. (2005), Aplikasi Analisis Multivariate Dengan Program SPSS, Ketiga., Badan Penerbit Universitas Diponegoro, Semarang.

Harjanti, T.T. and Tandelilin, E. (2007), "Pengaruh Firm Size, Tangible Assets, Growth Opportunity, Profitability, Dan Business Risk Pada Struktur Modal Perusahaan Manufaktur Di Indonesia: Studi Kasus Di BEJ”, Jurnal Ekonomi E Bisnis (JEB), Vol. 1 No. 1.

Haron, R. (2014), "Key Factors Influencing Target Capital Structure of Property Firms in Malaysia.", Asian Social Science, Vol. 10 No. 3.

Lim, T.C. (2012), "Determinants of Capital Structure Empirical Evidence from Financial Services Listed Firms in China”, International Journal of Economics and Finance, Vol. 4 No. 3.

Modigliani, F. and Miller, M.H. (1958), "The Cost of Capital, Corporation Finance and the Theory of Investment", The American Economic Review, Vol. 3, pp. 261-297.

Munawir, S. (2014), Analisa Laporan Keuangan, Edisi Keem., Penerbit Liberty, Yogyakarta.

Rus, P.A.M.R.B.M. and Ghazali, Z.B. (2014), "Firm and Macroeconomic Determinants of Debt: Pakistan Evidence", Procedia - Social and Behavioral Sciences, Vol. 172.

Sartono, A. (2014), Manajemen Keuangan Teori Dan Aplikasi, Penerbit BPFE UGM, Yogyakarta.

Seftianne and Handayani, R. (2011), "Faktor-Faktor yang Mempengaruhi Struktur Modal Pada Perusahaan Publik Sektor Manufaktur”, Jurnal Bisnis Dan Akuntansi, Vol. 13 No. 1.

Shah, A. and Khan, S. (2007), "Determinants of capital structure: Evidence from Pakistani panel data.", International Review of Business Research Papers, Vol. 3 No. 4, pp. 265-282.

Trinugroho, I. and Rinofah, R. (2011), "The Effect of Mispricing on Investment of Indonesian Firms: Do Financial Constraints Matter?", Middle Eastern Finance and Economics, No. 9. 